\title{
SISTEM REKOMENDASI PEMILIHAN SEKOLAH MENENGAH ATAS (SMA) SEDERAJAT KOTA MALANG MENGGUNAKAN METODE AHP-ELECTRE DAN SAW
}

\author{
Suherni Prahesti ${ }^{1}$, Dian Eka Ratnawati ${ }^{2}$, Heru Nurwasito ${ }^{3}$ \\ 1,2,3Fakultas Ilmu Komputer Universitas Brawijaya \\ Email: 19akunnyaherni@gmail.com, ${ }^{2}$ dian_ilkom@ub.ac.id, ${ }^{3}$ heru@ub.ac.id \\ (Naskah masuk: 4 Januari 2017, diterima untuk diterbitkan: 3 Februari 2017)
}

\begin{abstract}
Abstrak
Pendidikan merupakan aspek yang penting bagi masyarakat. Salah satu jenjang pendidikan formal adalah pendidikan menengah yaitu Sekolah Menengah Atas (SMA). Sekolah adalah lembaga yang memberikan pengajaran untuk siswa dibawah pengawasan guru. Setiap tahun ajaran baru, siswa akan memilih sekolah terbaik yang sesuai dengan keinginannya. Terdapat banyak pilihan sekolah dengan berbagai tawaran yang diberikan. Dengan begitu, calon siswa akan mengalami kesulitan dalam menentukan sekolah yang sesuai dengan kriteria yang diinginkan. Penelitian ini bertujuan untuk memberikan rekomendasi sekolah berdasarkan kriteria yang diinginkan oleh calon siswa dengan menerapkan metode AHP-ELECTRE dan SAW ke dalam sistem. Metode AHP digunakan dalam pembobotan dari setiap kriteria, metode ELECTRE melakukan klasifikasi alternatif yang masuk ke dalam kelompok direkomendasikan, dan SAW melakukan perankingan alternatif. Untuk pengujian, hasil pengujian akurasi sistem adalah sebesar 82,98\%. Hasil akurasi didapatkan dengan membandingkan hasil rekomendasi sistem dengan data yang telah didapatkan.
\end{abstract}

Kata kunci: pendidikan, SMA, AHP, ELECTRE, SAW

\begin{abstract}
Education is the important aspect for society. One of the education formal stages is, Senior High School. School is the institution which gives a preaching for students in teacher's control. In every new school year, students will choose the best school that they want. There is a lot of choices of school with various offer is given. So, the student candidate will have a trouble in deciding school which is fit in with the criteria that they want. This research is purpose to gives a recommendation for school based on criteria that student wants with applying AHPELECTRE and SAW method into a system. AHP method is used for weighting every criteria, ELECTRE method did an alternative classification into the group recommended, and SAW method did a ranking of alternatives. For testing, the results of accuracy test on system is $82,98 \%$. The accuracy of the results obtained by comparing the recommendations data on the system with the data that has been obtained.
\end{abstract}

Keywords: education, senior high school, AHP, ELECTRE, SAW

\section{PENDAHULUAN}

Sekolah adalah sebuah lembaga yang dirancang untuk mengajarkan siswa dibawah pengawasan guru yang bertujuan untuk mengembangkan siswa melalui proses pembelajaran. Jenjang pendidikan formal terdiri atas pendidikan dasar, pendidikan menengah dan pendidikan tinggi. Untuk pendidikan menengah terdiri atas pendidikan menengah umum dan pendidikan menengah kejuruan. Pendidikan menengah berbentuk sekolah menengah atas (SMA), madrasah aliyah (MA), sekolah menengah kejuruan (SMK), dan madrasah aliyah kejuruan (MAK).

Pemilihan sekolah merupakan salah satu hal yang sangat penting dikarenakan pilihan sekolah akan mempengaruhi pendidikan masa depan. Di era globalisasi saat ini membuat keputusan untuk memilih sekolah yang tepat tidaklah mudah. Selain jumlah sekolah yang banyak, setiap sekolah juga memberi beragam tawaran dan pilihan kepada para calon siswanya (Uyun, 2011). Beberapa calon siswa juga memiliki kriteria mengenai sekolah yang akan dipilih, mulai dari letak sekolah, prestasi yang pernah dicapai oleh sekolah, kegiatan ekstrakurikuler, fasilitas dan sarana prasarana yang dimiliki sekolah. Maka dari itu, dalam pemilihan sekolah para orang tua dan siswa pasti akan menyeleksi sekolah-sekolah dengan predikat yang terbaik dan sesuai dengan keinginan.

Para orang tua dan calon siswa untuk menentukan sekolah yang tepat dengan kriteriakriteria yang diinginkan pasti akan menemui kesulitan. Apalagi bagi mereka yang tidak memiliki banyak waktu untuk mensurvei semua sekolah yang ada di daerah tempat tinggal mereka atau daerah baru (Uyun, 2011). Dengan berkembangnya teknologi informasi saat ini, penggunaan teknologi informasi seperti sistem rekomendasi diharapkan dapat memberikan solusi dalam membantu proses pengambilan keputusan terkait permasalahan pemilihan sekolah. 
Penelitian sebelumnya mengenai penggunaan metode AHP dilakukan oleh Johan I., dimana penelitian yang dilakukan tersebut menggunakan metode AHP dan SAW. Kedua metode tersebut digunakan untuk menentukan Line $U p$ dalam cabang olahraga futsal. Metode AHP digunakan untuk penghitungan bobot dari masing-masing kriteria dan SAW digunakan untuk perankingan. Hasil pengujian akurasi menghasilkan nilai sebesar $87,273 \%$. Terdapat 48 data uji yang cocok dan 7 data uji yang tidak cocok dari total 55 data yang diujikan (Ismail, 2015).

Penelitian yang dilakukan oleh Fennia M. dengan menggunakan metode ELECTRE dan SAW untuk seleksi penerimaan peserta didik baru di SMA Brawijaya Smart School (BSS) kota Malang. Metode ELECTRE digunakan untuk menentukan peserta didik yang layak diterima dan metode SAW digunakan untuk menentukan peserta didik yang diterima dalam kelompok keminatan tertentu. Hasil dari penelitian ini, pengujian fungsionalitas memiliki tingkat kesesuaian presentase sebesar $100 \%$, hasil pengujian akurasi sistem dengan metode ELECTRE dan SAW memiliki tingkat kesesuaian yang didasarkan pada data hasil seleksi penerimaan peserta didik baru SMA BSS pada tahun 2014/2015 dengan presentase tertinggi sebesar $84,37 \%$ dan terendah sebesar 44\% (Maghfiroh, 2015).

Penelitian lainnya yang dilakukan oleh Ibnu Aqli dengan menggunakan 3 metode yaitu metode AHP ELECTRE dan TOPSIS. Dimana penggunaan ketiga metode tersebut untuk memberikan rekomendasi dalam pemilihan Sekolah Menengah Atas Sederajat di Kota Malang. Dengan membandingkan data rekomendasi yang dikeluarkan oleh sistem dengan data yang didapat dari pakar diperoleh hasil pengujian akurasi sistem sebesar 82,98\%(Aqli,2016).

Dalam penelitian ini akan digunakan metode AHP-ELECTRE dan SAW. Metode AHP digunakan sebagai pembobotan kriteria. Metode ELECTRE digunakan untuk pengelompokan data alternatif, dimana dalam pengelompokan tersebut terdiri atas kelompok rekomendasi dan tidak direkomendasikan. Metode SAW digunakan untuk perankingan hasil, perankingan yang dilakukan berdasarkan hasil data alternatif kelompok yang direkomendasikan.

Dengan menggunakan ketiga metode tersebut, diharapkan dapat memberikan rekomendasi dalam pemilihan Sekolah Menengah Atas.

\subsection{BATASAN MASALAH}

1. Data yang digunakan dalam penelitian ini adalah data Sekolah Menengah Atas Sederajat di Kota Malang.

2. Data yang digunakan diperoleh dari Website resmi Dinas Pendidikan Kota Malang (data PPDB tahun 2011-2015) dan Website dari masing-masing sekolah SMA Sederajat di Kota Malang. Data yang diperoleh antara lain rayon, nilai maksimal dan minimal, pagu, prestasi akademik dan prestasi non akademik, ekstrakurikuler dan fasilitas.

3. Metode yang digunakan merupakan penggabungan metode AHP, ELECTRE dan SAW tanpa membandingkan dengan metode yang lain.

4. Kriteria-kriteria yang digunakan antara lain jarak sekolah, nilai, prestasi yang dimiliki sekolah, fasilitas yang dimiliki sekolah dan ekstrakurikuler yang dimiliki sekolah.

\section{TINJAUAN PUSTAKA}

Berikut hasil penelitian-penelitian sebelumnya yang terkait atau memiliki kesesuaian dengan sistem rekomendasi dengan menggunakan metode AHP, ELECTRE dan SAW. Ditunjukkam pada Tabel 1.

Tabel 1. Tinjauan Pustaka

\begin{tabular}{|c|c|c|}
\hline No. & Judul & Hasil \\
\hline 1. & $\begin{array}{l}\text { Pemodelan Sistem } \\
\text { Pendukung } \\
\text { Keputusan } \\
\text { Penentuan Line Up } \\
\text { dalam Cabang } \\
\text { Olahraga Futsal } \\
\text { Menggunakan } \\
\text { Metode AHP- } \\
\text { SAW (Studi Kasus } \\
\text { : Hefotris } \\
\text { FILKOM UB) } \\
\text { (Ismail, 2015) }\end{array}$ & $\begin{array}{l}\text { Hasil berupa } \\
\text { penentuan Line } \\
\text { Up tim futsal } \\
\text { Hefotris. Tingkat } \\
\text { akurasi sebesar } \\
87,273 \% \text {. }\end{array}$ \\
\hline 2. & $\begin{array}{l}\text { Rekomendasi } \\
\text { Kecocokan } \\
\text { Tanaman } \\
\text { Hortikultura } \\
\text { Berdasarkan } \\
\text { Komposisi } \\
\text { Struktur Tanah } \\
\text { Pada Kota Batu } \\
\text { Menggunakan } \\
\text { Metode SAW } \\
\text { (Rachmawati, } \\
\text { 2015) }\end{array}$ & $\begin{array}{l}\text { Hasil berupa } \\
\text { rekomendasi } \\
\text { lahan yang } \\
\text { cocok dan } \\
\text { terdapat } 25 \text { lahan } \\
\text { yang tidak valid } \\
\text { dengan pakar. } \\
\text { Tingkat akurasi } \\
\text { sebesar } 83 \% \text {. }\end{array}$ \\
\hline 3. & $\begin{array}{l}\text { Sistem Pendukung } \\
\text { Keputusan Seleksi } \\
\text { Penerimaan } \\
\text { Peserta Didik Baru } \\
\text { Menggunakan } \\
\text { Metode } \\
\text { ELECTRE dan } \\
\text { SAW (Studi } \\
\text { Kasus: SMA } \\
\text { Brawijaya Smart } \\
\text { School Kota } \\
\text { Malang) } \\
\text { (Maghfiroh, 2015) }\end{array}$ & $\begin{array}{l}\text { Hasil berupa } \\
\text { rekomendasi } \\
\text { peserta didik } \\
\text { yang diterima } \\
\text { berdasarkan } \\
\text { kelompok } \\
\text { peminatan } \\
\text { tertentu. Tingkat } \\
\text { akurasi sebesar } \\
84,37 \% \text {. }\end{array}$ \\
\hline
\end{tabular}




\subsection{ANALYTICAL HIERARCHY PROCESS (AHP)}

Analitycal Hierarchy Process (AHP) adalah suatu model pendukung keputusan yang dikembangkan oleh Thomas L. Saaty. Model pendukung keputusan ini akan menguraikan masalah multi faktor atau multi kriteria yang kompleks menjadi suatu hirarki. Dengan hirarki, masalah yang kompleks dapat diuraikan ke dalam kelompokkelompoknya dan kemudian diatur sehingga permasalahan akan terlihat lebih terstruktur dan sistematis (Saragih, 2013).

Prinsip kerja AHP adalah menyederhanakan suatu persoalan kompleks yang tidak terstruktur, strategik, dan dinamik menjadi bagian-bagiannya, serta menata dalam suatu hirarki. Kemudian tingkat kepentingan setiap variabel diberi nilai numeric secara subjektif tentang arti penting variabel tersebut secara relatif dibandingkan dengan variabel lain (Faisal, 2015). Proses metode AHP dapat dilihat pada Gambar 1.

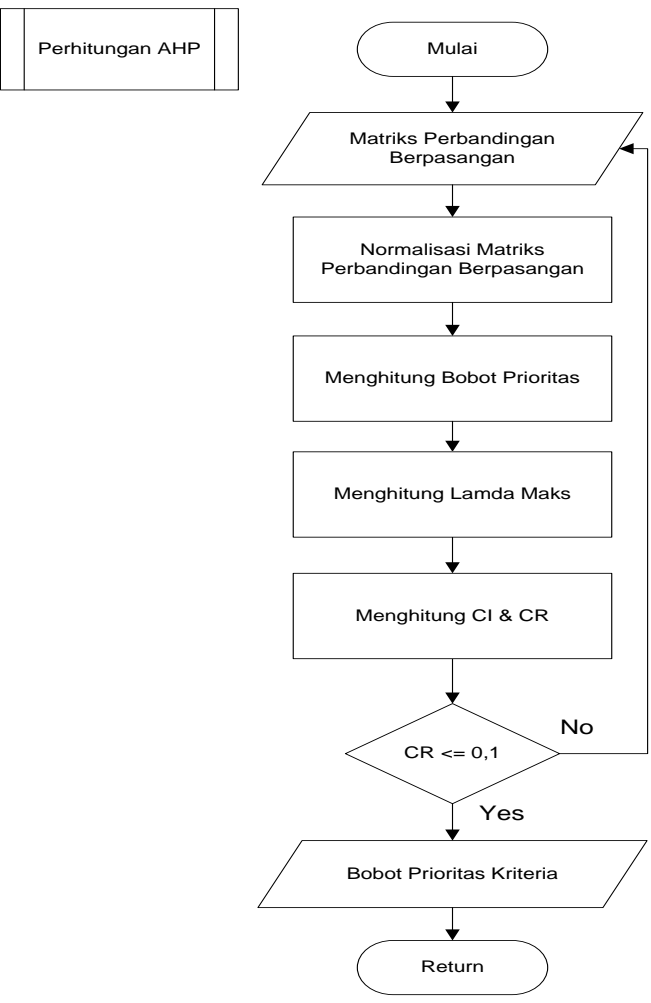

Gambar 1. Diagram Alir Metode AHP

\subsection{ELIMINATION ET CHOIX TRANDUISANT LA REALITE (ELECTRE)}

Yang pertama kali menggunakan konsep hubungan outranking untuk memperkenalkan metode Elimination and Choice Expressing Reality (ELECTRE) adalah Roy (1968) dan Benayoun et al. (1966). Sejak saat itu, berbagai model ELECTRE mulai berkembang berdasarkan permasalahan yang ada untuk menemukan solusi kernel atau untuk perankingan urutan alternatif, tingkat signifikansi kriteria harus diperhitungkan (benar atau semu) dan informasi preferensial (bobot, indeks concordance, indeks discordance, efek veto) (Tzeng, 2011).

ELECTRE merupakan salah satu metode pengambilan keputusan multikriteria berdasarkan pada konsep outranking dengan menggunakan perbandingan berpasangan dari alternatif-alternatif berdasarkan setiap kriteria yang sesuai (Pareira, 2014). Proses metode ELECTRE dapat dilihat pada Gambar 2.

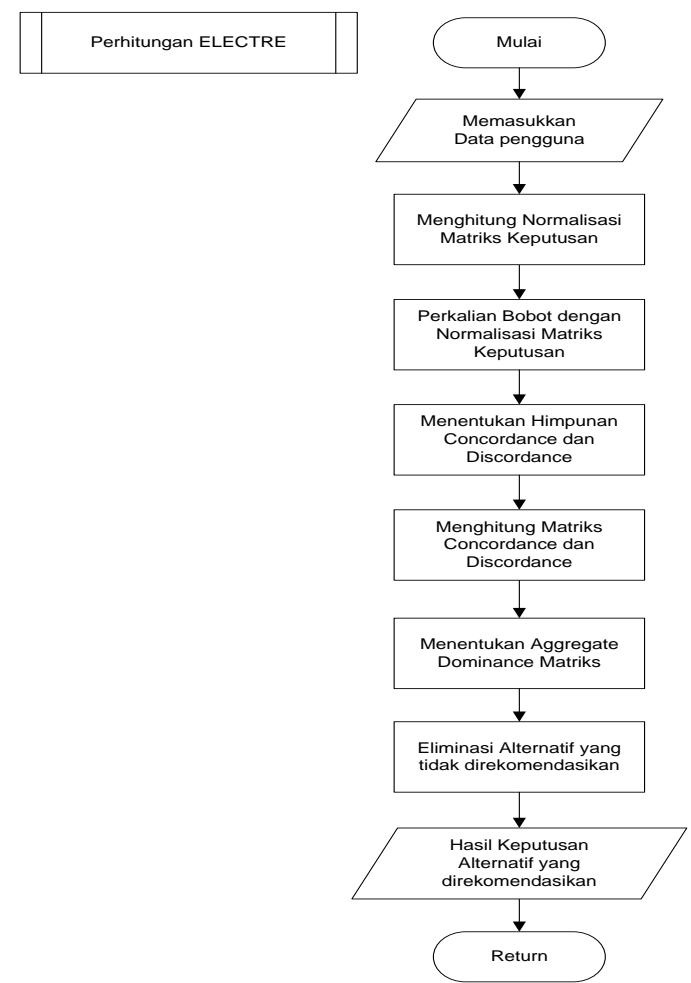

Gambar 2. Diagram Alir Metode ELECTRE

\subsection{SIMPLE ADDITIVE WEIGHTING (SAW)}

Metode Simple Additive Weighting (SAW) juga dikenal dengan istilah metode penjumlahan terbobot. Konsep dasar SAW adalah mencari penjumlahan terbobot dari rating kinerja pada setiap alternatif pada semua atribut. Metode SAW membutuhkan proses normalisasi matriks keputusan (X) ke suatu skala yang dapat diperbandingkan dengan semua alternatif yang ada (Tobing, 2014). Proses metode SAW dapat dilihat pada Gambar 3. 


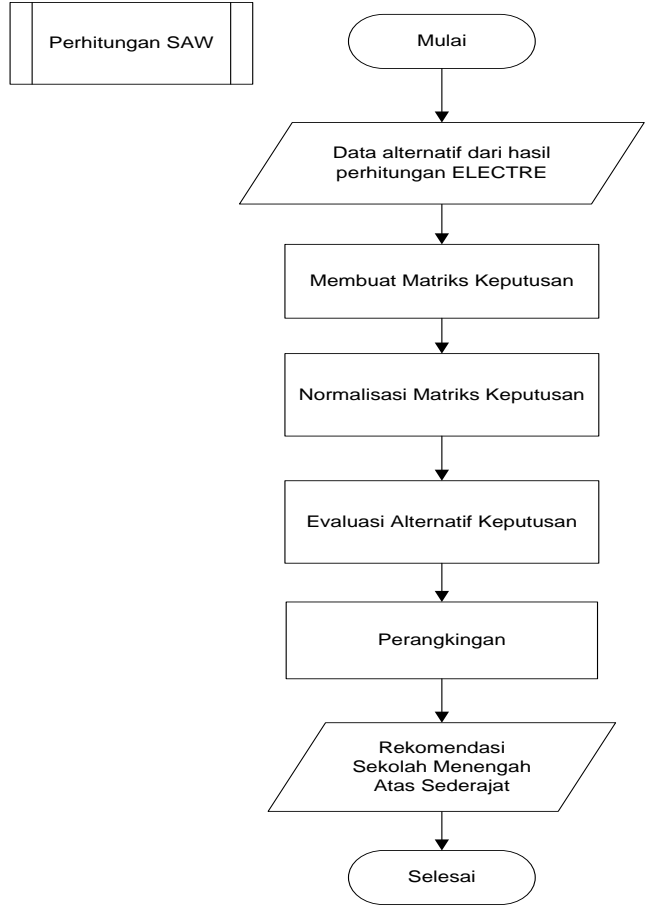

Gambar 3. Diagram Alir Metode SAW

\section{METODE}

Penelitian ini menggunakan 3 metode yaitu AHPELECTRE dan SAW. Ketiga metode tersebut digunakan untuk menghasilkan rekomendasi sekolah sesuai dengan masukkan dari pengguna. Diagram alir sistem secara umum terlihat pada Gambar 4.

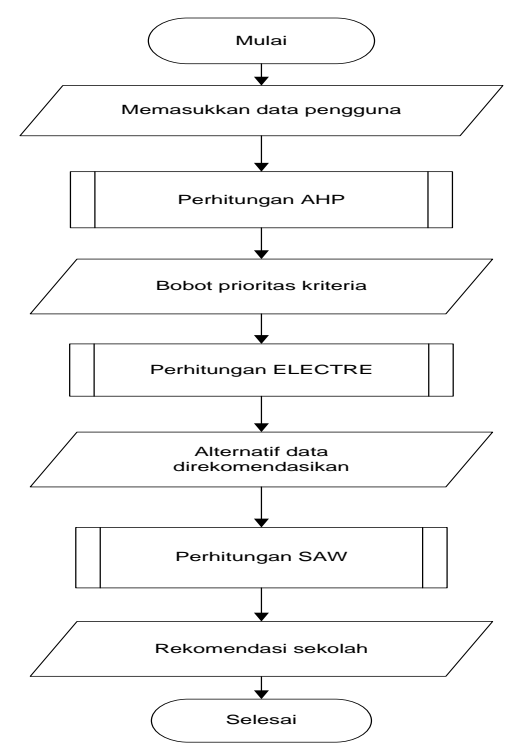

Gambar 4. Diagram Alir Sistem Secara Umum

Dalam perancangan sistem rekomendasi pemilihan sekolah menengah atas (SMA) Sederajat di Kota Malang ini pengguna akan diminta untuk memasukkan kriteria-kriteria yang diinginkan dalam memilih sekolah. Dari masukkan pengguna tersebut data akan diproses menggunakan metode AHPELECTRE dan SAW.
Metode yang digunakan pertama kali adalah metode AHP digunakan untuk pemberian bobot pada setiap kriteria yang diberikan kepada pengguna. Setelah hasil perhitungan metode AHP yang berupa bobot prioritas kriteria telah didapatkan selanjutnya akan digunakan dalam perhitungan metode ELECTRE. Dimana perhitungan ELECTRE digunakan untuk mengelompokkan data alternatif yang dibagi menjadi 2 kelompok yaitu kelompok data yang direkomendasikan dan tidak direkomendasikan. Data alternatif kelompok yang direkomendasikan selanjutnya dihitung pada metode SAW selanjutnya, sedangkan data kelompok yang tidak direkomendasikan akan dieliminasi. Alternatif kelompok data direkomendasikan ini selanjutnya akan digunakan pada metode SAW untuk dilakukan perankingan. Sehingga didapatkan hasil urutan rekomendasi sekolah yang paling mendekati kriteria.

Alur perancangan metode yang digunakan terlihat pada Gambar 5.

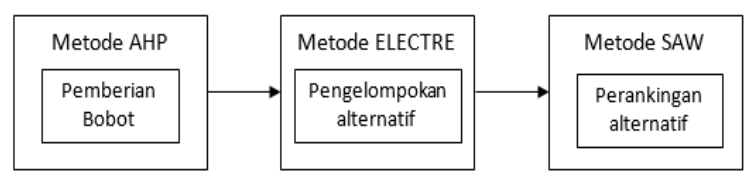

Gambar 5. Alur Perancangan Metode

Dari Gambar 5 diatas, data masukkan pengguna dihitung menggunakan metode AHP terlebih dahulu, setelah metode AHP menghasilkan bobot kriteria, selanjutnya dihitung menggunakan metode ELECTRE untuk pengelompokan alternatif, kelompok alternatif yang masuk ke dalam kelompok direkomendasikan akan digunakan pada metode SAW untuk dilakukan perankingan hasil alternatif.

\section{PENGUJIAN DAN ANALISIS}

Pengujian akurasi sistem adalah dengan membandingkan data hasil rekomendasi sekolah dari sistem dengan data hasil survey. Tujuan dari pengujian adalah untuk mengetahui banyaknya data yang sesuai antara hasil dari sistem dengan hasil survey. Dikatakan sesuai apabila hasil dari sistem mengeluarkan rekomendasi sekolah yang masuk ke dalam ranking 5 besar dan rekomendasi sekolah tersebut terdapat pada data hasil survey.

Skenario pengujian adalah pengguna memasukkan data pribadi dan mengisi kriteriakriteria yang diinginkan. Kemudian diproses oleh sistem dengan menggunakan 3 metode yaitu metode AHP, ELECTRE dan SAW. Hasil keluaran dari sistem merupakan perankingan hasil perhitungan metode SAW. Dimana hasil perankingan tersebut merupakan urutan yang termasuk ke dalam 5 besar. Apabila hasil sekolah yang direkomendasikan oleh sistem masuk ke dalam ranking 5 besar maka sudah sesuai dengan data hasil survey.

Hasil pengujian dengan data uji sebanyak 47. Diperoleh data yang sesuai sebanyak 39, sedangkan 
data yang tidak sesuai sebanyak 8. Sehingga didapatkan akurasi sistem dengan perhitungan sebagai berikut :

$$
\text { Akurasi }=\frac{47-8}{47} \times 100 \%=82,98 \%
$$

Nilai akurasi tidak mencapai $100 \%$ dikarenakan adanya data hasil dari sistem tidak mengeluarkan rekomendasi sekolah yang sesuai dengan data survey dan tidak masuk ke dalam ranking 5 besar. Pada pengujian metode ELECTRE hasil yang didapat tidak mencapai $100 \%$, sehingga pada pengujian metode SAW hasil akurasinya tidak mencapai $100 \%$. Karena, perolehan ranking sekolah yang masuk ke dalam 5 besar pada metode SAW berasal dari kelompok yang direkomendasikan pada perhitungan metode ELECTRE. Hasil pengujian metode SAW terdapat hasil yang tidak sesuai, dikarenakan pada perhitungan metode ELECTRE terdapat sekolah yang masuk ke dalam kelompok direkomendasikan sesuai dengan data survey, tetapi pada perhitungan metode SAW sekolah tersebut tidak masuk ke dalam ranking 5 besar. Hasil pengujian sistem terlihat pada Gambar 6.

\section{HASIL PENGUJIAN SISTEM}

$17,02 \%$

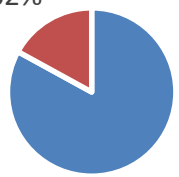

$82,98 \%$

- SESUAI $\quad$ TIDAK SESUAI

Gambar 6. Hasil Pengujian Sistem

\section{KESIMPULAN}

Berdasarkan hasil perancangan, implementasi, dan pengujian yang telah dilakukan pada bab sebelumnya, maka dalam penelitian ini dapat diambil kesimpulan :

1. Sistem rekomendasi pemilihan SMA Sederajat kota Malang menggunakan 3 metode yaitu metode AHP, ELECTRE dan SAW. Metode AHP digunakan dalam pemberian bobot kriteria yang akan digunakan pada metode selanjutnya. Metode ELECTRE digunakan dalam pengelompokan data alternatif yang masuk ke dalam kelompok yang direkomendasikan, untuk data dalam kelompok yang tidak direkomendasikan akan dieliminasi. Kelompok yang direkomendasikan tersebut digunakan dalam metode SAW untuk dilakukan perankingan data alternatif sekolah dimana dalam melakukan ranking diambil alternatif sekolah ke dalam 5 besar.

2. Nilai akurasi dari pengujian sistem dengan menggunakan 47 data uji didapatkan hasil akurasi sebesar $82,98 \%$. Dengan hasil yang didapatkan berasal dari pengelompokkan data alternatif yang masuk ke dalam kelompok yang direkomendasikan. Hasil akurasi sistem tidak dapat mencapai lebih dari 82,98\% karena pada metode ELECTRE yang dilakukan pengelompokkan data, memiliki akurasi yang tidak lebih dari $82,98 \%$. Hal ini dapat terjadi karena sistem dalam memberikan rekomendasi mempertimbangkan prestasi sekolah, ekstrakurikuler sekolah dan fasilitas sekolah. Sedangkan dalam kenyataannya setiap sekolah memiliki prestasi, ekstrakurikuler dan fasilitas sekolah yang berbeda-beda.

\section{DAFTAR PUSTAKA}

AQLI, I., EKA, D. R. \& DATA M. 2016. Sistem Rekomendasi Pemilihan Sekolah Menengah Atas Sederajat Kota Malang Menggunakan Metode AHP ELECTRE dan TOPSIS. Jurnal Teknologi Informasi dan Ilmu Komputer (JTIIK) FILKOM UB Vol. 3 No. 4.

AWANG, R. S., 2006. Analisis Pemilihan Sekolah Menengah Atas Semarang Berdasarkan Efektifitas Jarak, Saran Angkutan Umum dan Tingkat Unggulan Sekolah dengan Menggunakan Sistem Informasi Geografis dan AHP. Universitas Negeri Semarang.

FADLIL, J., MAHMUDY, WF., 2007. Pembuatan Sistem Rekomendasi Menggunakan Decision Tree dan Clustering. Kursor Vol. 3, No. 1.

FAISAL, PERMANA, S., 2015. Sistem Penunjang Keputusan Pemilihan Sekolah Menengah Kejuruan Teknik Komputer dan Jaringan yang Terfavorit dengan Menggunakan MultiCriteria Decision Making. Jurnal Teknologi Informasi dan Ilmu Komputer Vol. 2, No. 1. Universitas Trilogi.

FAUZI, W., 2016. Sistem Pendukung Keputusan Penerima Bantuan Dana Rutilahu dengan Menggunakan Metode ELECTRE. Universitas Jenderal Achmad Yani.

ISMAIL, J., 2015. Pemodelan Sistem Pendukung Keputusan Penentuan Line Up dalam Cabang Olahraga Futsal Menggunakan Metode AHPSAW (Studi Kasus : Hefotris FILKOM UB). DORO : Repositori Jurnal Mahasiswa PTIIK Universitas Brawijaya, Vol. 6, No. 29.

KUSRINI, GOLE, A., 2007. Sistem Pendukung Keputusan Penentuan Prestasi Pegawai Nakertrans Sumba Barat di Waikabubak. STMIK AMIKOM Yogyakarta, SNATI 2007.

MAGHFIROH, F., 2015. Sistem Pendukung Keputusan Seleksi Penerimaan Peserta Didik Baru Menggunakan Metode ELECTRE dan $S A W$. DORO : Repositori Jurnal Mahasiswa PTIIK Universitas Brawijaya, Vol. 5 No. 3.

MUFIZAR, T., 2015. Sistem Pendukung Keputusan Pemilihan Dosen Berprestasi di STMIK Tasikmalaya Menggunakan Metode Simple 
30 Jurnal Teknologi Informasi dan Ilmu Komputer (JTIIK), Vol. 4, No. 1, Maret 2017, hlm. 25-30

Additive Weighting (SAW). CSRID Journal, Vol. 07 No. 3. STMIK Tasikmalaya.

PANDUAN PPDB KOTA MALANG. 2015. Malang

PAREIRA O., JOKO S., ARDANARI P., 2014. Sistem Pendukung Keputusan Pemilihan Tempat Wisata di Timor Leste dengan Metode ELECTRE. S2. Universitas Atma Jaya Yogyakarta.

PERMENDIKNAS RI. 2007. Standar Pengelolaan Pendidikan Oleh Satuan Pendidikan Dasar dan Menengah (Peraturan Menteri Pendidikan Nasional Republik Indonesia Nomor 19 Tahun 2007).

RACHMAWATI, 2015. Rekomendasi Kecocokan Tanaman Hortikultura Berdasarkan Komposisi Struktur Tanah Pada Kota Batu Menggunakan Metode SAW. DORO : Repositori Jurnal Mahasiswa PTIIK Universitas Brawijaya, Vol. 5 No. 18.

SARAGIH, S. H., 2013. Penerapan Metode Analitycal Hierarchy Process (AHP) pada Sistem Pendukung Keputusan Pemilihan Laptop. STMIK Budi Darma Medan.

TOBING, G., L., 2014. Sistem Pendukung Keputusan Pemilihan Jurusan pada Sekolah Menengah Kejuruan (SMK) Negeri 1 Siatas Barita dengan Metode Simple Additive Weighting (SAW). STMIK Budi Darma Medan.

TRISNAWARMAN, D., LIVEREJA, M., 2006. Aplikasi Sistem Pendukung Keputusan Pemilihan Sekolah. Universitas Tarumanagara Jakarta.

TZENG, G., HUANG, J., 2011. Multiple Attribute Decision Making Methods and Applications. CRC Press.

UYUN, S., MADIKHATUN, Y., 2011. Model Rekomendasi Berbasis Fuzzy untuk Pemilihan Sekolah Lanjutan Tingkat Atas. Jurnal Informatika Vol 5, No. 1. Universitas Islam Negeri Sunan Kalijaga. 